\title{
Effect of Metformin Therapy on Low Density Lipoprotein (LDL) Levels in Type 2 Diabetes Mellitus Patients at Undata Hospital in Palu City Central Sulawesi
}

\section{(Efek Terapi Metformin terhadap Level Low Density Lipoprotein (LDL) pada Pasien Diabetes Mellitus Tipe 2 pada RS Undata di Kota Palu Sulawesi Tengah)} \author{
E-mail: : teatriyu02@gmail.com \\ Article Info: \\ Received: 24 August 2021 \\ in revised form: 14 February 2022 \\ Accepted: 20 February 2022 \\ Available Online: 3 March 2022 \\ Keywords: \\ DM type 2 \\ metformin \\ LDL \\ Corresponding Author: \\ Tri Yulianti \\ Department of Pharmacy \\ Faculty of Mathematics and Natural \\ Sciences \\ Tadulako University \\ Palu \\ 90245 \\ Indonesia \\ e-mail: teatriyu02@gmail.com
}

Alwiyah Mukaddas ${ }^{1}$, Amelia Rumi $^{1}$, Tri Yulianti ${ }^{1 *}$

${ }^{I}$ Department of Pharmacy, Faculty of Mathematics and Natural Sciences, Tadulako University, Palu, Indonesia.

\begin{abstract}
Background: Metformin, which can control blood glucose levels, can reduce LDL levels in type 2 DM patients. Objectives: To determine the mean value of pre and post LDL in type 2 DM patients after receiving metformin therapy for three months. Methods: This study used a crosssectional study with a prospective approach, It was done by conducting pre and post examination of LDL levels using metformin. This study was analyzed using the SPSS Wilcoxon statistical test. The total sample that met the inclusion and exclusion criteria was 18 respondents. Results: This study used a single metformin value ( $\mathrm{sig}=0.000<0.05)$ with a baseline mean value of $148.22 \mathrm{mg} / \mathrm{dL}$ and an evaluation of $133.56 \mathrm{mg} / \mathrm{dL}$ where the difference in reduction was $14.66 \mathrm{mg} / \mathrm{dL}$. Conclusion: There was a decrease in LDL levels in type 2 DM patients after using metformin for three months.
\end{abstract}

Keywords: DM type 2, metformin, LDL

Copyright $@ 2019$ JFG-UNTAD

This open access article is distributed under a Creative Commons Attribution (CC-BY-NC-SA) 4.0 International license.

How to cite (APA 6th Style):

Mukaddas, A., Rumi A., Yulianti, T. (2022). Effect of metformin therapy on low density lipoprotein (LDL) levels in patients with type 2 diabetes mellitus at Undata Hospital in Palu City Central Sulawesi. Jurnal Farmasi Galenika: Galenika Journal of Pharmacy (e-Journal), 8 (1), 22-30. doi: 10.22487/j24428744.2022.v8.i1.15596 


\section{ABSTRAK}

Latar Belakang: Metformin yang dapat mengontrol kadar glukosa darah dapat menurunkan kadar LDL pada pasien DM tipe 2. Tujuan: Untuk mengetahui rerata nilai pre dan post LDL pada pasien DM tipe 2 setelah mendapat terapi metformin selama tiga bulan. Metode: Penelitian ini menggunakan studi potong lintang dengan pendekatan prospektif, dilakukan dengan melakukan pemeriksaan pra dan pasca pemeriksaan kadar LDL menggunakan metformin. Penelitian ini dianalisis menggunakan uji statistik SPSS Wilcoxon. Jumlah sampel yang memenuhi kriteria inklusi dan eksklusi adalah 18 responden. Hasil: Penelitian ini menggunakan nilai metformin tunggal ( $\mathrm{sig}=0,000<0,05$ ) dengan nilai mean baseline $148,22 \mathrm{mg} / \mathrm{dL}$ dan evaluasi $133,56 \mathrm{mg} / \mathrm{dL}$ dimana selisih penurunannya adalah 14,66 mg/dL. Kesimpulan: Terjadi penurunan kadar LDL pada pasien DM tipe 2 setelah penggunaan metformin selama tiga bulan.

Keywords: DM tipe 2, metformin, LDL

\section{INTRODUCTION}

Diabetes mellitus is a condition in which the increasing glucose levels in the blood occurs when the insulin produced by the pancreas is not enough or it can also occur when the body is unable to properly use of insulin (Nuraisyah, 2017). In 2011, there were 336 million people in the world who suffered from T2DM and reached 4.6 million deaths each year. The International Diabetes Federation (IDF) states that DM sufferers will increase by 9.1 million people and become 14.1 million people in 2035. In Indonesia it is ranked 5th worldwide, in 2013 it increased by 7.6 million people. According to the Central Sulawesi Provincial Health Office, in 2015 there were 10,851 diabetes mellitus. In 2015 cases of diabetes mellitus amounted to $0.82 \%$ and increased in 2016 was $1.28 \%$.

Metformin is an oral hypoglycemic drug widely used in type 2 diabetes mellitus. Metformin is widely used because it does not cause a boost in the insulin secretion process and cannot cause a deficiency in blood glucose. Metformin can also cause weight loss in a person. Metformin absorption occurs in the intestine and will enter the circulation but is not bound to plasma proteins; metformin is excreted in the urine without changing the form of the compounds. The half-life of metformin is about 2 hours. can use metformin because it cannot cause hypoglycemia,(Amaral et al., 2013)

Metformin induces the activation of adenosine monophosp protein kinase (AMPK) limiting the anabolic pathway and stimulating the catabolic pathway. AMPK in the heart, can inhibit sterol regulatory element-binding protein 1 (SREBP-1c) which is responsible for controlling genes needed in the lipogenesis process. This downregulation activates fatty acid desaturase (FADS), which reduces arachidonic acid levels. This reduction can lead to the increasing in membrane fluidity which functions in maintaining the function and integrity of the cell membrane, thereby increasing the recycling of low density lipoprotein cholesterol (LDL-C) receptors and reducing LDL-C levels.(van Stee, de Graaf, \& Groen, 2018). In several studies, metformin monotherapy had a significant effect on reducing LDL levels. This is evidenced by research conducted by Lin et al., (2018) where metformin can reduce LDL levels in patients with type 2 diabetes mellitus. With the paired test analysis, the LDL levels were obtained, namely the initial LDL level of $111 \mathrm{mg} / \mathrm{dL}$ to $102 \mathrm{mg} / \mathrm{dL}$. So it can be concluded that metformin has a significant effect on LDL levels.

In 2018, the Hospital in Palu has the number of patients with type 2 diabetes mellitus of 970 people with 426 people using metformin alone or in combination. So, the usage of metformin at the Undata Hospital Palu reached $43.9 \%$ or around $44 \%$. Therefore, it is interested to know the effect of metformin on LDL levels in patients with type 2 diabetes mellitus a hospital in Palu, Central Sulawesi.

\section{METHODS}

Prior to conducting the research, a request for Etchical Clearance was submitted to the Health Research Ethics Commission (HREC), Faculty of Medicine, Tadulako University and has been appointed with the number 6084/UN 28.1.30/KL/2020. All research subjects were asked for their 
consent to be included in the study in the form of written informed consent. Before giving approval to the prospective research subject, they are given an explanation of the objectives, benefits, and research procedures. The identity of research subjects is kept confidential and is not published without the permission of the research subjects. All costs related to research are borne by the researcher.

This research is observational with analytical. The Research design was a cross sectional study which was conducted prospectively. This research was conducted at the Cardiac Center of the Hospital in Palu, Central Sulawesi. The research took place in the period of January-April 2020. The populations of this study were all patients with type 2 diabetes mellitus undergoing outpatient treatment a hospital in Palu, Central Sulawesi. The samples of this study were type 2 diabetes mellitus patients who met the inclusion criteria, namely those who received metformin treatment at a Hospital in palu and excluded patients, namely patients who did not want to continue the research, the patients died and patients taking hypolipidemic drugs. In this study, patients with a low level of education were patients who only studied up to primary school and junior high school, and in the moderate criteria patients who studied up to senior high school or vocational school, while patients who had higher education were patients who went to university. The method of taking blood patient is insert the cholesterol strip into the meter lipid pro and press the button ON. The on the meter lipid pro screen will blink when the meter is ready for the blood. Clean finger to be lancep with an alcohol swab. Prick patient finger with a lancing divide then take blood it using a blood draw stick. then put the blood sample to the test area of the strip until you hear a beep sound.test result appears in 2 minutes. The sampling technique used in this study was purposive sampling technique met the inclusion criteria in and the sampling in this study was for 3 months using a lipid pro.

\section{Data Analysis}

Data analysis using univariate method for patient characteristics and the bivariate analysis method to see the relationship between the independent variables and the dependent variable studied and the Wilcoxon non-parametric statistical test was carried out to see changes in Low Density Lipoprotein (LDL) levels before and after using metformin.

\section{RESULTS AND DISCUSSION}

\section{Sample}

The total sample obtained in research conducted a Hospital in Palu, Central Sulawesi province, amounted to 18 patients who used a single metformin. This study is limited by the presence of the COVID-19 pandemic which resulted in the sample being used with 18 patients.

\section{Demographic Characteristics}

Table 1 Demographic characteristics of type 2 Diabetes Mellitus patients

\begin{tabular}{ccc}
\hline Patient Characteristics & $\begin{array}{c}\text { Patients } \\
(\mathbf{n = 1 8})\end{array}$ & $\begin{array}{c}\text { Percentage } \\
(\mathbf{\%})\end{array}$ \\
\hline Age & & \\
<45 years & 1 & 5,6 \\
$\geq 45$ years & 17 & 94.4 \\
\hline Gender & & \\
Male & 4 & 22.2 \\
Women & 14 & 77.8 \\
Level of Education & & \\
Low (Primary school, Junior high school) & 13 & 72.2 \\
Medium (Senior High School, Vocational School) & 2 & 11.1 \\
Higher (University) & 3 & 16.7 \\
\hline
\end{tabular}




$\begin{array}{ccc}\text { Profession } & & \\ \text { Farmer } & 1 & 5,6 \\ \text { Housewife } & 7 & 38.9 \\ \text { Entrepreneur } & 5 & 27.8 \\ \text { Retired } & 5 & 27.8\end{array}$

In table 1, Demographic characteristics of type 2 Diabetes Mellitus patients a hospital in Palu Central Sulawesi Province in 2020 It was obtained data that patients with Type 2 Diabetes Mellitus were more common in the age group $\geq 45$ years, namely 17 respondents $(94.4 \%)$. In research conducted by (Trisnawati \& Setyorogo, 2013) found that the age group that suffered from diabetes mellitus a lot was $\geq 45$ years, namely 24 respondents $(75.0 \%)$. The increase in diabetes occurs with increasing age which begins with an increase in glucose intolerance. The aging process reduces the ability of pancreatic beta cells to produce insulin. In addition, in older people there was a 35\% decrease in mitochondrial activity in muscle cells, this is associated with increased levels of fat in muscle which lead to insulin resistance. On research(Isnaini \& Ratnasari, 2018) that with increasing age each individual can affect the decline in all body systems, one of which is the endocrine system which causes insulin resistance conditions which results in unstable blood sugar levels so that there is a relationship between age factors and the incidence of diabetes mellitus.

Research based on gender in diabetes mellitus patients at Undata Hospital, Central Sulawesi province, found that seven respondents (77.8\%) were female. According to research (Isnaini \& Ratnasari, 2018), as many as 40 respondents $(75.5 \%)$ showed that women are more at risk of diabetes mellitus than men due to hormonal and metabolic factors. Women experiencing menopause contribute to the distribution of the increased amount of body fat accumulated very quickly due to this process, so women are more at risk of developing type 2 diabetes. Along with increasing age in women so that they experience menopause which can cause a decrease in the hormone estrogen, where the hormone estrogen plays a role in maintaining blood glucose balance. One of the factors that cause type 2 diabetes mellitus is obesity. Physically, women have a greater chance of obesity than men, because obese women cause insulin sensitivity so that blood glucose will accumulate in the form of fat in the body.

Patient characteristics based on education level were mostly in the low education category $72.2 \%$ (13 patients). This research shows that in the low category, more respondents are affected by DM than the higher education level category, because people with low education have little knowledge, so there are still many who have not maintained their diet, exercise, and awareness about maintaining health compared to respondents. who have a higher education category which will usually have a lot of knowledge in preventing disease. Research conducted by(Trisnawati \& Setyorogo, 2013) shows the same results, namely low category respondents who are at risk of type 2 diabetes mellitus with 19 respondents $(67.9 \%)$. According to research (Wahyu, 2017) that education is related to knowledge, because it is through the level of education that we can learn the process of achieving quality of life, especially in health.

Based on the occupational category, it was found that patients with the status of housewives experienced more diabetes, namely 38.9\% (7 patients), according to the study. (Isnaini \& Ratnasari, 2018)that most respondents as housewife and all women. Work as a housewife includes light physical activity and has erratic work time, if humans rarely exercise, the food substances that enter the body are not burned but are stored in the body in the form of fat and glucose, if insulin is not enough to convert glucose into energy then this is what causes type 2 diabetes mellitus. When physically active, glucose can be converted into energy. when doing physical activity will increase insulin so that glucose levels in the blood decrease. Research (Agustina, Diani, \& Agianto, 2017) Housewives have a high risk of developing DM because of a lack of healthy lifestyle, lack of knowledge about diabetes, poor adherence to diabetes treatment, and rarely do physical activities or exercise. 


\section{Clinical Manifestations}

Table 2. Manifestations of Type 2 DM patients.

\begin{tabular}{ccc}
\hline Clinical Manifestations & Number of Patients $(\mathbf{n = 1 8})$ & Percentage $(\%)$ \\
\hline Dizzy & 9 & $50 \%$ \\
Fatigue & 4 & $22.2 \%$ \\
Headache & 3 & $16.7 \%$ \\
Leg cramps & 1 & $5.6 \%$ \\
Blurry eyes & 2 & $11.1 \%$ \\
\hline
\end{tabular}

This study obtained clinical manifestations in type 2 DM patients with complaints of dizziness, there were nine respondents (50\%), according to research conducted by (Insiyah \& Hastuti, 2016) that the symptoms often experienced by respondents were dizziness, weakness even though they did not do heavy work, blurred vision, fatigue, headache and tingling in the legs. Feeling dizzy in type 2 DM patients is caused by changes in blood sugar levels, if the amount of blood glucose levels fluctuates a lot, the more likely a person is experiencing dizziness(Alfiah Kusuma Wardani, 2014).

\section{Complementary Diseases}

Table 3 Comorbidities for type 2 DM patients.

\begin{tabular}{ccc}
\hline Complementary Diseases & Number $(\mathbf{n}=\mathbf{1 8})$ & Percentage $(\%)$ \\
\hline Coronary heart & 13 & $72.2 \%$ \\
Osteoatritis & 2 & $11.1 \%$ \\
Enlarged prostate & 1 & $5.6 \%$ \\
Immune disorders & 3 & $16.7 \%$ \\
Heart failure & 2 & $11.1 \%$ \\
Dyspepsia & 3 & $16.7 \%$ \\
\hline
\end{tabular}

Table 3 shows that 13 patients $(72.2 \%)$ were diagnosed with coronary heart disease. According to research conducted by(Idrus, 2019)that most of the patients with diabetes mellitus had heart disease by $73.4 \%$ of respondents. Increased blood glucose levels in the body that exceed normal limits in diabetes mellitus cause various cardiovascular diseases such as coronary heart disease, blockage of peripheral blood vessels.(Agustina et al., 2017). Diabetes mellitus patients have increased blood glucose levels as a result of which blood viscosity can also be increased, making the heart work harder to pump blood throughout the body. Increased glucose in the blood also causes fat levels to increase and stick to the walls of blood vessels. This sticking fat causes constriction of the blood vessels so that blood flow is interrupted, the attached fat can also cause blood vessels to become hard or a buildup of fatty plaque and blockage of blood vessels that causes narrowing of blood flow to the heart, this event is called atherosclerosis (Utami \& Azam, 2019).

\section{Treatment Profile}

Table 4 Treatment therapy given to type 2 diabetes mellitus patients

\begin{tabular}{ccc}
\hline Medicines & Number of Patients $(\mathbf{n = 1 8})$ & Percentage $(\boldsymbol{\%})$ \\
\hline Metformin & 18 & $100 \%$ \\
Vitamin B1,B6,B12 & 4 & $22.2 \%$ \\
Flunarizine HCL & 1 & $5.6 \%$ \\
\hline
\end{tabular}




$\begin{array}{ccc}\text { Meloxicam } & 2 & 11.1 \% \\ \text { Clopidogrel bisulfat } & 3 & 16.7 \% \\ \text { Diclofenac Sodium } & 1 & 5.6 \% \\ \text { Bisoprolol fumarate } & 1 & 5.6 \% \\ \text { Asetilsalisilat } & 4 & 22.2 \% \\ \text { Nitrogliserin } & 1 & 5.6 \% \\ \text { bisoprolol } & 7 & 38.9 \% \\ \text { Isosorbid dinitrat } & 2 & 11.1 \% \\ \text { Lansoprasol } & 1 & 5.6 \% \\ \text { Omeprazole } & 1 & 5.6 \% \\ \text { Candesartan cilexetil } & 1 & 5.6 \%\end{array}$

Based on research conducted on patients with type 2 diabetes mellitus at Undata Hospital, Central Sulawesi Province, 18 people (100\%) found the drug that was widely used, it is the biguanid group, the drug metformin. According to (Jonathan, K. et all, 2019) 25 patients (21.7\%) used metformin alone in Bandung City Hospital. Metformin is the first-line therapy in type 2 DM patients which has the main effect of reducing gluconeogenesis and improving glucose uptake in peripheral tissues by 10 $40 \%$. In addition, metformin can also reduce lipid profiles.

Metformin, which is a biguanid drug class that works to improve insulin sensitivity, inhibits glucose formation in the liver, and suppresses appetite (almasdy, et all, 2015). Metformin is a widely used diabetes therapy. However, metformin itself often causes reactions in the form of drug side effects such as gastrointestinal disturbances, diarrhea, nausea, vomiting, flatulence. Risk factors that arise without food intake and other influencing factors, namely factors of how to take medication, drug dose of metformin and patient age(Jonathan, K. et all, 2019).

Metformin used in diabetes mellitus patients is a dose of $500 \mathrm{mg} /$ day and is used twice a day for initial use for 1 week, can be increased according to the patient's condition. The daily dose of metformin is $2000 \mathrm{mg} / \mathrm{day}$, given after meals. Research conducted by(Porter et al., 2014) in a Pekanbaru hospital that metformin $500 \mathrm{mg}$ was used by respondents $2 \mathrm{x}$ a day with a daily dose of 1000-1500 mg / day with 53 respondents (55.2\%). Research (Almasdy et al., 2015) that metformin can reduce LDL (Low Density Lipoprotein) levels.

Evaluation of LDL (Low Density Liporotein) Levels

Table 4 Value before and after levels of LDL using a single metformin in patients with type 2 diabetes mellitus

\begin{tabular}{ccccc}
\hline Evaluation & \multicolumn{2}{c}{ Average $(\mathbf{n}=\mathbf{1 8})$} & \multirow{2}{*}{ Difference } & $\begin{array}{c}\boldsymbol{P} \\
\text { Parameters (LDL) }\end{array}$ \\
\cline { 2 - 3 } Metformin single & Baseline & Evaluation & & Value \\
\hline
\end{tabular}

The results of the evaluation of LDL levels using a single metformin in table 4.8 showed an average baseline LDL of $148.22 \mathrm{mg} / \mathrm{dl}$ and a decrease in evaluation was $133.56 \mathrm{mg} / \mathrm{dl}$. Significant reduction in LDL levels in patients receiving metformin single at a $P$ value $(0.000<0.05)$. Research result (Lin et al., 2018) There were 155 respondents with type 2 diabetes mellitus, LDL levels decreased significantly ( <0.001), the initial LDL level was $111 \mathrm{mg} / \mathrm{dl}$ and the final LDL level was $102 \mathrm{mg} / \mathrm{dl}$ and metformin could reduce LDL levels by $9 \%$ whereas in this study metformin reduce LDL levels by $14.66 \%$ this is because the number of samples used is different.

Research conducted by (Sugiarto et al., 2018) that metformin can also reduce LDL by $(P=0.012$ $<0.05)$, Metformin which can affect lipid metabolism in T2DM patients. Metformin induces activation of AMPK (Adenosine Monophosphate Protein Kinase)which regulates the energy changes that work 
by limiting the anabolic pathway (the process of forming simple compounds into complex compounds) and stimulating the catabolic pathway (the process of breaking down complex compounds into simple compounds). AMPK in the liver can inhibit SREBP-1c (Sterol Regulatory Element-Binding Protein 1) responsible for controlling the genes needed in the lipogenesis process. The SREBP-1c gene was also found to be regulated by metformin. This downregulation activates FADS (fatty acid desaturase), which reduces arachidonic acid levels. Arachidonic acid is present in the membranes of body cells and is abundant in the brain, muscles and liver. This reduction can lead to an increase in membrane fluidity which functions in maintaining the function and integrity of the cell membrane, thereby increasing the recycling of LDL-C receptors and reducing LDL-C levels. (van Stee et al., 2018).

\section{CONCLUSION}

The conclusion of this study is that LDL levels before using metformin were $148.22 \mathrm{mg} / \mathrm{dl}$ after using metformin alone for three months, LDL levels decreased significantly, namely LDL levels to 133.56 $\mathrm{mg} / \mathrm{dl}$ with $P$ value $(\mathrm{sig}=0.000<0,05)$.

\section{ACKNOWLEDGEMENT}

I would like to thank the staff of Undata Hospital in Palu Central Sulawesi

\section{CONFLICT OF INTEREST}

The authors declare that there is no conflict of interest

\section{REFERENCES}

ADA. (2018). Standards of Medical Care in Diabetes. 41.

Agustina, RM, Diani, N., \& Agianto. (2017). Nusantara Medical Science Journal. 14-18.

Alfiah Kusuma Wardani, MAI (2014). Relationship of family support and control of blood sugar levels with symptoms of microvascular complications. Sinta Indonesia, 2 (1), 1-12.

Almasdy, D., Sari, DP, Suhatri, S., Darwin, D., \& Kurniasih, N. (2015). Evaluation of the Use of Antidiabetic Drugs in Type-2 Diabetes Mellitus Patients in a Padang City Government Hospital West Sumatra. Journal of Pharmaceutical \& Clinical Science, 2 (1), 104. https://doi.org/10.29208/jsfk.2015.2.1.58

Almatsier. (2014). Diet Guide. Jakarta: Gramedia Main Library.

Amaral, G., Bushee, J., Cordani, UG, KAWASHITA, K., Reynolds, JH, ALMEIDA, FFMDE,... Junho, M. do CB (2013). Type 2 Diabetes Mellitus. In Journal of Petrology (Vol. 369). https://doi.org/10.1017/CBO9781107415324.004

Aritrina, P., Marzuki, A., \& Mangarengi, F. (2016). Analysis of Low Density Lipoprotein Cholesterol Levels as a Risk Factor for Complications in Type 2 Diabetes Mellitus Patients. Journal of Medicine Unhas, 4, $\quad 5 . \quad$ Retrieved from http://ojs.uho.ac.id/index.php/medula/article/viewFile/2556 / 1906

Beckman, J. (2015). Global E\&P. In Offshore (Vol. 72). International Diabetes Federation.

Diabetes Care. (2014). Diagnosis and Classification of Diabetes Mellitus. Diabetes Care, 37 (SUPPL.1), 81-90. https://doi.org/10.2337/dc14-S081

Dipiro TT, Wells BG, ST. and DC. (2017). Pharmacotherapy Handbook. UK: McGraw-Hill Education Companies. 
Hasani, N. (2018). Evaluation of Oral Antidiabetic Dosing and Drug Interactions in Type 2 Diabetic Patients. Evaluation of Oral Antidiabetic Dosing and Drug Interactions in Type 2 Diabetic Patients, 7 (4), 191-196. https://doi.org/10.22146/jmpf.33263

Hassan, MH, \& Abd-Allah, GM (2015). Effects of metformin Plus Gliclazide Versus Metformin Plus Glimepiride on Cardiovascular Risk Factors in Patients with Type 2 Diabetes Mellitus. Pakistan Journal of Pharmaceutical Sciences, 28 (5), 1723-1730.

Idrus, HH (2019). Analysis of Diabetes Mellitus Factors on Coronary Heart Disease (CHD) Patients at the Indonesian Air Force Dr. Dody Sarjoto Makassar Hospital. UMI Medical Journal, 2 (2), 1-7. https://doi.org/10.33096/umj.v2i2.20

Insiyah, I., \& Hastuti, RT (2016). Level of Knowledge and Compliance About DIIT Diabetes Mellitus in Diabetes Mellitus Patients at Sibela Public Health Center, Surakarta City. Interest: Journal of Health Sciences, 5 (1), 14-21. https://doi.org/10.37341/interest.v5i1.8

Isnaini, N., \& Ratnasari. (2018). Risk factors Affect the Incidence of Type Two Diabetes mellitus. Aisyiyah's Journal of Midwifery and Nursing, 14 (1), 59-68. https://doi.org/10.31101/jkk.550

Jonathan, K., Kuswinarti., Soetedjo, N, M. (2019). Pattern of Oral Antidibetes for Type 2 Diabetes Mellitus Patients in the Internal Medicine Section of the Bandung City Hospital in 2017. CDK277 / vol 46 no. 6 th 2019

Ministry of Health RI Research and Development Agency. (2018). Main Results of Basic Health Research. Ministry of Health, Republic of Indonesia, 1-100. https://doi.org/1 December 2013

Lin, SH, Cheng, PC, Tu, S. Te, Hsu, SR, Cheng, YC, \& Liu, YH (2018). Effect of Metformin Monotherapy on Serum Lipid Profile in Statin-Naïve Individuals with Newly Diagnosed Type 2 Diabetes Mellitus: a Cohort Study. PEERJ, 6.Retrievedfromhttps: //www.ncbi.nlm.nih.gov/pmc/articles/PMC5899882/

Nuraisyah, F. (2017). Risk Factors for Type 2 Diabetes Mellitus. Public Health Sciences Program Ahmad Dahlan University Public Health Faculty, 13 (2), 120-127.

Pernicova, I., \& Karbonits, M. (2014). Metformin-Mode of Action and Clinical Implications for Diabetes and Cancer. 10, 143. Retrieved from https://pumed.ncbi.nlm.nih.gov/24393785

Porter, J., Hulbert-Williams, L., Chadwick, D., Vicary, S., Young, A., Hicks, S.,... Barker, C. (2014). Pattern of Oral Anti-Hyperglycemic Drug Use in Type 2 Diabetes Mellitus Patients Hospitalized at X Pekan Baru Hospital in 2014. Disability and Rehabilitation, 20 (1), 87-108. https://doi.org/10.1080/14768320500230185

Soeharso. (2014). Heart Attacks and Strokes Have to do with Fat and Cholesterol. Jakarta: Gramedia Main Library.

Sugiarto, HP, D., H, G., D, M., A, T., \& Kunci, K. (2018). The Role of Metformin in Atherogenic Dyslipidemia in Metabolic Syndrome with Diabetes Mellitus Type-2 Which is Poorly Treated. Yarsi Journal of Medicine, 17 (3), 169-183.

Tandra. (2017). a Complete Guide to Knowing and Overcoming Diabetes Quickly and Easily the 2nd edition. Jakarta: IKAPI.

Trisnawati, SK, \& Setyorogo, S. (2013). Risk Factors for Type II Diabetes Mellitus in Puskesmas Cengkareng Subdistrict, West Jakarta, 2012. Health Scientific Journal, 5 (1), 6-11. 
Utami, NL, \& Azam, M. (2019). Incidence of Coronary Heart Disease in Patients with Diabetes Mellitus. HIGEIA (Journal of Public Health Research and Development), 3 (2), 311-323. https://doi.org/10.15294/HIGEIA.V3I2.23692

Van Stee, MF, de Graaf, AA, \& Groen, AK (2018). Actions of Metformin and Statins on Lipid and Glucose Metabolism and Possible Benefits of Combination Therapy. Cardiovascular Diabetology, 17 (1), 1-22. https://doi.org/10.1186/s12933-018-0738-4

Wahyu, D. (2017). Factors Related to Compliance in Diet Management in Outpatients with Diabetes Mellitus Type 2 in Semarang City. Journal of Health Education, 2 (2), 137-145. https://doi.org/10.15294/jhe.v2i2.14448

WHO. (2015). Global Report on Diabetes. Retrieved from https://books.goggle.co.id/books?world+health+organisation.+(2015).global+report+on+diabetes + france\&ots=DJZzYhYrl\&sig. 